\title{
Cambridge Değişimi ve bir Zorunlu Soru: Bir Nesne Olmak Ne demektir?
}

\section{Cambridge Change and a Necessary Question: What is it to be an Object?}

\author{
Egemen Seyfettin Kuşcu ${ }^{1}$ (])
}

'Dr. Öğr. Üyesi, İstanbul Üniversitesi, Edebiyat Fakültesi, Felsefe Bölümü, İstanbul, Türkiye

ORCID: E.S.K. 0000-0001-8549-5927

\section{Sorumlu yazar/Corresponding author: Egemen Seyfettin Kuşcu İstanbul Üniversitesi, Edebiyat Fakültesi, Felsefe Bölümü, İstanbul, Türkiye \\ E-posta/E-mail: egemenk@istanbul.edu.tr}

Başvuru/Submitted: 05.10.2020

Kabul/Accepted: 09.11.2020

Atıf/Citation: Kuscu, Egemen Seyfettin. (2020). “Cambridge Değişimi ve bir Zorunlu Soru: Bir Nesne Olmak Ne demektir?" Felsefe Arkivi-Archives of Philosophy, 53: 1-24. https://doi.org/10.26650/arcp.843068

\section{ÖZET}

Analitik felsefe özellikle metafizik karşıtı bir yaklaşım içerisinde olmakla nitelendirilmiştir. Ancak 20. yüzyılda bu gelenekte önemli dönüşümler yaşanmıştır. Dile dönüş ile başlayan tartışmalar sonrasında metafiziğe dönüşü ortaya çıkarmıştır. Bugün açık bir biçimde analitik metafizik ya da ontolojilerden söz edilebilmektedir. Elbette farklı ontolojiler farklı varolanlar ve farklı kategorileştirmeleri merkezlerine koymaktadırlar. 20. yüzyııın başında değişimin ne olduğu konusunda ortaya konan görüşler de çağdaş ontoloji tartışmalarında değişim konusunun ayrı bir başlık olarak ele alınabilmesi için bir zemin yaratmıştır. Farklı felsefi yaklaşım içerisinde olmalarına rağmen McTaggart ve Russell benzer bir felsefe yapma tarzı içerisindedirler. Bu kısmi benzerlik Geach'in her iki düşünürün değişim konusundaki yaklaşımlarını tek bir başlık altında, aynı şekilde değerlendirmesine yol açmıştır. Geach bu filozofların değişim tanımlarını her iki filozofun da Cambridge Üniversitesinde olmalarından kaynaklı Cambridge Değişimi olarak adlandırmış ve görüşlerini eleştirmiştir. Geach Cambridge Değişiminin gerçek değişimleri gölgede bıraktığını, tüm değişimleri aynılaştırdığını iddia etmektedir. Bu yazıda Geach'in eleştirisinin haklı olmadığı, kendi önerisinin başka bazı öncüllere gerek duyduğu üzerinden gösterilmeye çalışılmaktadır. Geach gerçek değişimleri nesnede bir farklııı yaratan değişimler olarak tanımlamaktadır. Ancak bu tanım şu soruyu sormamızı gerektirir: Dilde özne yerindeki terimin gönderimi durumundaki nesne nedir? Nasıl bireyleşir ve bireyleşiminde hangi ontolojik varolanlar etkilidir? Bu sorular analitik metafizikte nesne kuramlarının ele alınmasını gerektirir. Dayanak ve Demet kuramlarının ele alınmasıyla ontolojik olarak özelliklerin önemi ortaya çıkmaktadır ancak bu Geach'in iddiasının yerinde olmadığını açık kılmaktadır. Bir nesne tartışması yapmadan bir değişim tartışması ve ona bağlı olarak özelliklerin derecelendirilmesinden söz edilemez.

Anahtar Kelimeler: Analitik metafizik, Cambridge Değişimi, nesne, dayanak, demet, özellikler

\section{ABSTRACT}

Analytical philosophy is often thought as anti-metaphysical. However, in the 20th century, important transformations have taken place in this tradition. After the debates that started with a linguistic turn, a metaphysical turn emerged. 
Nowadays, one can clearly speak of analytical metaphysics or ontologies. Different ontologies place different entities and categorizations at their center. The views put forward on 'what change is' at the beginning of the 20th century also created a ground for the change to be addressed as a separate topic in contemporary ontology discussions. Although they have a different philosophical approach, McTaggart and Russell share similar philosophical methods. This partial similarity caused Geach to evaluate both thinkers' approaches of definition of change under a single heading in the same way. Geach criticized these philosophers and called their definitions of change the 'Cambridge Change'. Geach argues that the Cambridge Change overshadows real changes, it makes all changes identical. In this article, we try to show that Geach's criticism is not justified and his proposal requires some other premises. Geach defines real changes as changes that make a difference in the object. But what is the object? This question requires a consideration of object theories in analytical metaphysics. With the consideration of the Substratum and the Bundle theories, the importance of the properties on an ontological basis emerges, but this makes it clear that Geach's claim is not well-founded. Without a discussion on objects, there is no discussion of change and the grading of properties depending on it.

Keywords: Analytic metaphysics, Cambridge Change, object, substratum, bundle, properties

\section{Giriş}

Çağdaş metafizik/ontoloji ${ }^{1}$ tartışmaları içerisinde değişim konusunda ortaya konan görüşler genellikle belli bir biçime sadık kalınarak yapılmaktadır. Bu biçim değişim konusunu zaman konusuyla birlikte ele almakla şekillenmiştir. Bu biçimin dışında bir başka etkili yaklaşım da özelliklerin ve nesnenin merkeze konmasıyla değişimin ele alınmasıdır. Şüphesiz her iki yaklaşımda, diğer bakış açısı bağlamında da görüşler ortaya konsa da bu yaklaşımların metafizik kabuller bakımından farklı oldukları açıktır. Ben de bu yazıda öncelikle ilk tarzın tartışma biçiminin içerisinde kalarak, söz konusu bakış açılarını sergileyerek değişim konusunda ne türden sınıflamalar yapıldı̆̆ını dile getirmeye çalışacağım. İkinci olarak da alternatif yaklaşım olarak ifade edilebilecek bakış açıları sergileyeceğim. Metinde daha özel olarak ise Geach tarafından Russell ve McTaggart’’n değişim konusundaki görüşlerini Cambridge Değişimi olarak niteleyen ve eleştiren Geach'in önerisinin aksine bir argüman geliştirmeye çalışacağım.

\section{Değişim, yargılar ve iki görüş̧}

Öncelikle başlıkta da dile getirdiğim "Cambridge Değişimi” olarak adlandırılarak literatürde yer etmiş olgunun anlaşılabilmesine faydalı olacak çağdaş felsefenin özellikle de çağdaş analitik felsefenin başlangıcındaki iki değişim tanımını ele alacağım. Bu sayede değişim konusunda sözünü ettiğim çağdaş tartışmaların nasıl bir zemine dayandıklarını anlama olanağı da ortaya

1 Çağdaş tartışmalar içerisinde bu iki kavram arasında anlam farklılığı olduğu açıktır. Metafizik kavramı kökleri Aristoteles'e kadar dayanan en genel olarak varlığın, varolanların neliğine yönelen bir araştırma olarak imlenirken, ontoloji özellikle Quine'nın da etkisiyle daha teknik ve basit bir sorunun cevabı peşindedir: Neler vardır? Ancak bu yazıda bu farkı öne çıkartmadan her iki kavramı birbirinin yerine kullanılabilir bir şekilde ele alacağız. İki kavram arası farklılıklar ve ilişkilere dair bkz. Michael J. Loux, Metaphysics: a contemporary introduction, (London: Routledge Taylor\&Francis Group, 2006), 1-15. 
çıkacaktır. ${ }^{2}$ Bu zemine dair Butchvarov "Şu anki analitik felsefe hakkındaki en çarpıcı olgu onun metafiziğe dönüşüdür" ${ }^{3}$ dedikten sonra analitik ontolojilerin en genel niteliğinin, ontolojik konularla doğrudan doğruya yüzleşmemeleri olduğunu dile getirmektedir. Ona göre doğrudan yüzleşme yerine ontolojik açıdan problemli oldukları varsayılan gündelik cümlelerimizin cümle çevrimi (paraphrasing) yoluyla ya da gündelik kullanımı yakalayacak tanımlamalarla ontolojik tavırlar geliştirilmektedir. ${ }^{4}$

Butchvarov'un tespiti çağdaş ontoloji tartışmalarında özellikle de 1950'li yıllar sonrasında daha da belirginleşen ancak diğer yandan da her zaman felsefenin gündeminde olan dil-ontoloji ilişkisine dikkatleri çekmektedir. Aşağıda ele alacağımız iki tavır her ne kadar işaret edilen yılların öncesinde olsa da bu bakış açısının gelişmesinde katkıları olan iki tavırdır.

\subsection{McTaggart ve değişim}

McTaggart zamanın varlığını yadsıdığı önemli makalesinde (ve elbette kitabında ${ }^{5}$ ) zaman konusunda iki bakış açısının var olduğunu ileri sürüp sonrasında bunları yanlışlayarak kendi görüşünü ortaya koymaktadır. ${ }^{6}$ Burada söz konusu argümanların başarılı olup olmamalarından ziyade sergilediği iki zaman anlayışını ve bunları değerlendirişini kısaca ele alacağız. McTaggart’a göre bu iki zaman anlayışı A ve B zaman anlayışları ya da kuramları olarak adlandırılabilir ve onların özlü ifadesi şu şekildedir:

"Kısa olması adına yakın geçmiş yoluyla uzak geçmişten şimdiye yönelen ve sonra da şimdiden yakın geleceğe ve uzak geleceğe yönelen konumların dizilerinden A serileri olarak söz edeceğim. Önceden sonraya yönelen konumlar dizilerinden de B serisi olarak söz edeceğim. Zamandaki bir konumun içerikleri, olaylar olarak adlandırılır. Tek bir konumun içerikleri, uygun olarak bir olaylar çoklusu olarak adlandırılması kabul edilmiştir.”’

Bu iki serinin örnekleri de şu şekilde verilebilir:

A: "X olayı iki gün sonradır (gelecektedir)." "X olayı şu andadır (şimdidedir)." "X olayı geçmiştedir" şeklinde zaman kipleri üzerinden, belirgin zaman noktalarına işaret etmek. ${ }^{8}$

B: "X olayı Y olayından öncedir." "X ve Y eşzamanlıdır." "X olayı Y olayından sonradır." şeklinde zaman ilişkileri kullanmak. ${ }^{9}$

2 Hem Giriş̧te sözünü ettiğimiz farklı yaklaşımların hem de çağdaş tartışmaların derli toplu bir değerlendirilişi için Bkz.: Chris Mortensen, "Change and Inconsistency", The Stanford Encyclopedia of Philosophy, ed. Edward N. Zalta, erişim: 16.11.2020, URL = <https://plato.stanford.edu/archives/spr2020/entries/change/ >.

3 Panayot Butchvarov, "The Ontology of Philosophical Analysis”, Nồs, Mar., 1981, Vol. 15, No. 1, 1981, 3.

4 Butchvarov, "The Ontology of Philosophical Analysis", 4.

5 J.M.E. McTaggart, Studies in the Hegelian Dialectic, (Cambridge: Cambridge University Press, 1922).

6 J.M.E. McTaggart, "The Unreality of Time”, Mind, 17(68) (1908): 457-474.

7 McTaggart, "The Unreality of Time", 458.

8 McTaggart, "The Unreality of Time”, 458.

9 McTaggart, "The Unreality of Time”, 458. 
McTaggart'ın konuyla ilgili değerlendirmesi birini diğerine indirgeme yoluyla açığa çıkar. B serileri aslında A serilerine bağlıdır ve onlara indirgenmelidir çünkü görülebileceği üzere sabit olaylar olmaksızın aslında B serilerinden söz edilemez ancak sabit olaylar da değişimden söz edilebilmesini engellemektedir. ${ }^{10}$ Bu yüzden B serilerinin A serilerine ihtiyacı vardır.

"Bu durumda A serileri olmadan değişim olmaz ve sonuç olarak B serileri kendi başlarına zaman değişimi içerdiğinden ötürü zaman için yeterli değillerdir. (...) Dolayısıyla değişimin, yalnızca olaylara A serilerindeki bulunuşları yoluyla verilen özelliklerin değişimi olduğu sonucuna varmamız gerekiyor gibidir. Ve bu özellikler de nitelikler ya da ilişkilerdir." 11

Ancak A serileri de bir çelişki barındırmaktadır çünkü aynı olgular farklı özellikleri taşır hale gelmektedir. A serisindeki bir X olayı hem 'iki gün sonra olma özelliğini' hem de 'üç gün önce olma özelliğini’ taşır hale gelir, dolayısıyla aslında hem tüm olaylar bu bağlamda aynılaşmaktadır hem de tek bir olay kendi içinde çelişik hale gelmektedir. ${ }^{12}$

Dolayısıyla zamanın gerçek-dışılığı, değişimin olanağı üzerinden tartışılmaktadır ve değişim olgusu da olayların belli özelliklerinin olup olmaması ve elbette söz konusu yargıların incelenmesi üzerinden ele alınmaktadır. ${ }^{13}$

Bu çağdaş dönemin bakış açısını anlamak adına ilk örneğimizdir ve dikkat çekici olan yan tartışmanın dilsel ifadelerin ontolojideki yerleri ile ne kadar ilişkili olduğudur. Nitekim bu dikkat çekici yan McTaggart’ın tezlerine günümüze değin karşı çıkmak adına yapılan tartışmalar ya da çağdaş bir ontoloji kitabının zaman-değişim başlıklarına baktığınızda etkisini hala gösteren bir yandir. ${ }^{14}$

Çağdaş dönemin karakterini anlamak için başvuracağımız ikinci örneğimiz de aslında McTaggart'ın felsefi yaklaşımının tam tersini savunmak adına yola çıkan ve felsefesini bu karşıtlık

10 "Bu durumda eğer bir A serisi olmadan bir B serisi zamanı oluşturabiliyorsa, değişim bir A serisi olmadan da olanaklı olmalıdır. Geçmiş, şimdi ve gelecek ayrımının gerçekliğe uygulanmadığını varsayalım. Değişim gerçekliğe uygulanabilir mi? Değişen durumdaki şey nedir?” McTaggart, “The Unreality of Time”, 459.

11 McTaggart, "The Unreality of Time”, 461. Buradaki açıklamadan da hareket ederek söz konusu serilerdeki özellikler A özellikleri ve B özellikleri olarak da adlandırılmaktadır.

12 McTaggart, "The Unreality of Time", 467

13 Dikkat edilirse doğrudan doğruya Taggart'ın konuya ilişkin kendi çözümlemesini, yani zaman konusundaki açıklamasına değinmedik. Bunun iki nedeni vardır: Birinci neden, önceliğimizin ileride ele alacağımız, Geach’in açıklamasına yol açan noktayı açığa çıkartmak olmasıdır, ikinci neden de McTaggart’ın kendi cevabının anlaşılabilmesi için felsefesinin detaylarına girme zorunluluğunun olmasıdır. Özellikle ikinci bağlamda Gözcü, Taggart'ın C-serilerini ortaya koyduğunu ancak bu serilerin görünüşün ardındaki Gerçekliğin serileri olmalarından kaynaklı McTaggart bağlamında asıl anlaşılması gerekenin görünüş-gerçeklik tartışmasının ne şekilde çözümlediğidir demektedir. Bu detaylara bu makalede yer vermedik. Bkz. A. Suat Gözcü, "ZAMAN SORUNU: ŞİMDİCİ VE EBEDİYETÇİ ZAMAN ANLAYIŞLARI”, Kutadgubilig Felsefe-Bilim Araştırmaları, Eylül 2018, Sayı 38, 50-1.

14 Loux analitik metafizik hattındaki tartışmaları yalnızca değişim-zaman konusunda değil sürekli metalinguistik yaklaşımlarla sadece dilsel olmayan yaklaşımların çatışmaları çerçevesinde sergilemektedir. "Bir kategori araştırması olarak” tanımladığı metafiziğin her başlığında süregiden tartışmalarda dilsel kavramsallaştırma ile karşılık geldikleri varolanlar ilişkisinin izi bulunmaktadır. Kategori araştırması nelerin olduğunun sayılıp dökülmesi işidir. Bkz. Loux, Metaphysics, 10-15. 
üzerine yapılandıracak olan B. Russell'dır. Elbette Russell, McTaggart'tan daha da yoğun biçimde analitik felsefenin ve çağdaş ontoloji tartışmalarının gelişim tarzını doğrudan etkilemiştir.

\subsection{B. Russell ve değişim}

Russell Matematiğin İlkeleri’nde değişimi iki önermenin doğruluk değerlerindeki fark bakımından tanımlamaktadır. Bu iki önermenin taşıdığı farklılık da aslında içerdikleri zamana ilişkin, özelliklere ilişkin ifadelerden ya da daha açık söylersek yüklemlerinden kaynaklanmaktadır:

"Değişim bir varolan (entity) ve bir T zamanıyla ilgili bir önerme ile aynı varolan ve bir başka T' zamanıyla ilgili bir önerme arasındaki, iki önermenin birinde T'nin görünmesi diğerinde de T' 'nün görünmesi olgusundan hareketle farklılık göstermeleri kaydıyla doğruluk ya da yanlışlık bağlamındaki farklılıktır. Önceki türden önermelerin sürekli anların serileri ile bağlaşımlı biçimde sürekli seriler oluşturdukları yerde değişim de süreklidir. Değişim böylece (1) sabit bir varolan ve (2) bu varolan ile bir diğer varolan ve hepsi değil ama bazı zaman anlarının üçlü ilişkisinden oluşur." 15

Russell'ın tanımı herhangi bir varolanın (ve elbette özellikle en geniş kullanımıyla bir terimin ${ }^{16}$ ) içerildiği bir önermenin bir $\mathrm{T}$ anına sahip olması sonra da aynı varolanın içerildiği bir diğer önermenin bir $\mathrm{T}_{2}$ anına sahip olmasından yola çıkmaktadır. Bu tanımın örneğini de şu şekilde verebiliriz:

A önermesi: X olayının ya da nesnesinin T anında Y’si vardır.

B önermesi: X olayının ya da nesnesinin $\mathrm{T}_{2}$ anında Y'si yoktur. ${ }^{17}$

Dolayısıyla eğer ki özne yerinde duran terimin karşılığını bir nesne, olay vb. olarak alırsak söz konusu varolanın farklı zamanlarda farklı özellikleri taşıması (örneklemesi) ya da taşımaması (örneklememesi) üzerinden değişim konusu tartışılabilir. ${ }^{18}$

15 Bertrand Russell, Principles of Mathematics, (London and New York: Routledge, 1937), 476-7.

16 "Düşüncenin nesnesi olan ne varsa, ya da herhangi bir doğru veya yanlış önermede ortaya çıkan ne varsa, ya da bir olarak sayılabilen ne varsa, buna terim diyorum. Bu, bu durumda felsefi söz dağarcı̆̆ında en geniş sözcüktür. Bunu birlik (unit), birey (individual) ve varolan (entity) ile eşanlamlı (synonymous) olarak kullanacağım. İlk ikisi her bir terimin bir olduğu olgusunu vurgulamaktayken, üçüncüsü her bir terimin bir varlığı olduğu olgusundan türetilmiştir, e.d. bir anlamda vardır. Bir insan, bir an, bir sayı, bir küme, bir ilişki, bir mitolojik canavar ya da söz edilebilir herhangi bir şey, elbette ki bir terimdir." Russell, Principles of Mathematics, 44.

17 Aslında bu örnekle hem Russell'ın hem de McTaggart'ın açiklamaları arasında bir fark bulunmadığı açığa çıkmaktadır. Her iki düşünür amaçları başka olsa da önermenin incelenmesi yoluyla tartışmayı yürütmektedir. Dolayısıyla her ne kadar açıklamalarında içkin olsa da özne yerinde duran terimin gönderimini açıktan açığa nesne, olay vb. tanımlarında geçirmemektedir.

18 Russell'ın bu bağlamda diğer kitaplarında daha yoğun biçimde ileri sürdüğü tümeller kuramını da anarak bu konuyu ele almamız gerekmektedir. Bkz.: Bertrand Russell, Felsefe Sorunları, çev. Vehbi Hacıkadiroğlu, (İstanbul: Kabalcı Yayınevi, 2000). Elbette Russell, Matematiğin İlkeleri’nde de benzer bir görüştedir. Yalnızca konuyu detaylandırmamıştır. 
Her iki bakış açısı da tartışmayı benzer bir sorgulama üzerinden yürütmektedir. Elbette Russell bu inceleme aracılığıyla sadece dil içerisinde kalarak bir tartışma yürütmemektedir. McTaggart'ın tam tersi bir çaba içerisindedir. İngiliz idealistlerine ${ }^{19}$ göre dünyanın bize her gün görünen hali birbirinden ayrı, belli ilişkilerle birbirleriyle ilişkili (bağıntılı) tekil varolanların ve onların arasındaki ilişkilerin (bağıntıların) oluşturduğu bir görünümdür. ${ }^{20} \mathrm{Bu}$ "görünüş" gerçeklikle karıştırılmaktadır. Oysaki gerçeklik bu görünüşün dışında yekpare, kendi içinde ayrımlı olmayan ve düşünsel bir bütündür. Hegel'in Mutlak görüşünün bir yansıması olan bu düşünce görünüşte ayrı ayrı görünen şeylerin bir içsel ilişki içerisinde birlikte düşünülmesi zorunluluğunu da ortaya koymaktadır. Bu bağlamda sağduyuya uygun olan bu dünyanın nesneleri ve onların birbirleriyle olan dışsal ilişkileri de yadsınmalıdır. Bu yadsıma ele aldığımız üzere zamanın varlığını da değişimin gerçekliğini de içermektedir.

Russell ilgili dönemde katı bir gerçekçi görüş içerisinde her türden terimin ve karşılık geldikleri varolanların (16 no'lu dipnotta bunları birbirinin yerine kullandığını da belirttik) gerçekliğinden yana bir tavır içerisindedir. Bu tavrı da sözünü ettiğimiz üzere idealist yaklaşımın görünüşün ardındaki yekpare gerçeklik iddiasının çürütülmesi amacıyla takınmaktadır. Bu noktada en önemli argümanı (felsefi yaşamı boyunca neredeyse hiç değiştirmediği argümanı) varolanlar arasında geçerli olan asimetrik bağıntıların varlığı ve gerçekliğidir. Bu bağıntıların gerçeklikleri ortaya konduğunda bağıntıların haklarında oldukları varolanların da birbirlerinden ayrı olduğu ortaya çıkacak ve kendisinin sözleriyle "aRb türünden her bağıntısal önermenin (ab)r olarak gösterilebilecek a ve b’nin oluşturduğu bütünü ilgilendiren bir önermeye çözülebileceğini”21 ileri süren monist (tekçi) ${ }^{22}$ kuram çürütülebilecektir. Asimetrik ilişkiler aynı zamanda birer özelliktir ${ }^{23}$ ve bu aynı zamanda bize bağıntı içindeki varolanları da anlama olanağı tanır. "A, B'den daha büyüktür (R)” önermesi iki önermeye ayrılarak incelenebilir: A'nın B'den büyük olması özelliğinin işaret edildiği bir önerme ve B'nin ise A'dan küçük olma özelliğine sahip olduğunu işaret eden bir diğer önerme. ${ }^{24}$ Böylece hem iki varolan birbirlerinden ayrı özellikler taşıyan ve de birbirinden ayrı iki varolan olarak ortaya konur hem de gerçeklikleri ve zihin-bağımsızlıkları kanıtlanmış olur.

Russell ile McTaggart'ın farklı olduğu açıktır ancak iki felsefe yapma tarzının benzerliği de açıktır. Aslında bu tarz bir yaklaşım, biraz da dönemin ruhudur denebilir. Yargıların incelenmesi yoluyla görünüşün ardına geçme tavrı her dönem filozofunun öncelikli hedefidir. Ancak her iki tarafın ulaşmak istediği hedefler kesinlikle farklıdır. Bir taraf en keskin ifadesiyle Bradley gibi bir tür yeni Parmenidesçiliği yüceltecekken diğer taraf bunu yermektedir ve değişim, zaman vb.

19 McTaggart'ın sözünü ettiğimiz eserleri haricinde Bradley'in çalışmaları da önemli ve etkilidir. Bkz.: H. F, Bradley, Appearance and Reality: a metaphysical essay, 6th Imp., (London: George Allen \& Unwin LTD, 1916).

20 Eğer mantıksal açıdan bakılırsa bağıntı karşılığı daha uygun görünmektedir ancak metafizik (ontolojik) bağlamda düşünüldüğünde ilişki daha yerinde bir ifade gibi durmaktadır.

21 Russell, Principles of Mathematics, 226.

22 Russell Bradley'in Appearance and Reality'de 31. Sayfada bu yaklaşımı monadistik kuram olarak nitelediğini de belirtmektedir. Russell, Principles of Mathematics, 226.

23 Bu konu yazının devamında ele alınacak tümel demetleri kuramları kısmında Russell bölümünde önem kazanacak, aynı zamanda Russell'ın bu konudaki düşünsel sürekliliği de takip edilebilecektir.

24 Russell, Principles of Mathematics, 225. 
tüm konularda şeylere ve onların değişimlerine, onların kendilerine dolayısıyla bir gerçekçiliğe erişmek istemektedir.

Bir sonraki başlıkta ele alacağımız Peter Geach bu iki tarz arasındaki benzerlikten hareket etmektedir. Dolayısıyla ilgili benzerliğin neye sebep olduğu açı̆̆a çıkacaktır. Ancak ilgili görüşe geçmeden Geach'in tavrının her iki düşünür açısından da yerinde olmadığı belirtilmelidir. Geach hem bu iki filozofu aynı torbaya atar hem de onların kuramlarını hayli çarpıtarak sunar ancak bu iki tavrı aynı çatı altında birleştirmesinin nedeni sözünü ettiğimiz dönem ruhudur. Lombart’a göre Geach'in Cambridge değişimi tanımı Russell'ın ya da McTaggart'ın değişim konusundaki tavırlarına uygun değildir. Russell bir nesnenin ne zaman değiştiğini anlamaya çalışırken McTaggart değişimin ne zaman ortaya çıktığını anlamak istemektedir. Geach ise hem ikisini de aynı torbaya atmakta hem de onların asıl niyetlerini perdelemekte ve görüşlerini yalnızca tek yanıyla sergilemektedir. ${ }^{25}$

\title{
2. P. Geach ve Cambridge Değişimi
}

Cambridge Değişimi ifadesi değişim (ya da zaman) konusunda ilgili olguyu anlamak adına çok geniş bir değişim tanımlaması yapanları ve bunda da yalnızca yargıların (daha da teknik dile getirilişi ile önermelerin) incelenmesi yolunu tutanları eleştirmek adına Peter Geach tarafından ortaya konmuştur. Geach ilgili nitelemeyi hem McTaggart'ın hem de Russell'ın Cambridge'de çalışmalarından hareketle, ikisini de kastederek kullanmaktadır:

\begin{abstract}
“Böylece 'gerçek' ilişkileri 'gerçek' değişimlerle bağladım. 'Gerçek' değişimler problemiyle ilgili başka yerde yazmıştım (Tanrı ve Ruh adındaki eserin indeksine bakılabilir, Routledge and Kegan Paul). ${ }^{26}$ 'gerçek' değişimleri, verili bir bireyselde edimsel olarak süregiden işlemleri ‘Cambridge’ değişimleri arasından ayırt etmemiz gerektiğini belirtmiştim. Bu yüzyılın ilk yıllarında basılmış Russell’ın Matematiğin İlkeleri ve McTaggart’n Varlığın Doğası gibi büyük Cambridge felsefi eserleri, değişimi yalnızca bireysellere farklı zamanlarda uygun olabilecek çelişkili nitelikler meselesi gibi açıklamışlardır. Elbette her değişim mantıksal olarak 'Cambridge' değişimini gerektirir ancak tersi elbette ki doğru değildir.”27
\end{abstract}

Geach değişim konusunda yalnızca ilgili değişim tanımından hareketle yapılacak bir tartışmanın aslında asıl değişimi (real change) gözden kaçırmamıza neden olduğunu ileri sürmektedir ve iki düşünürün tanımlarından hareketle kendi kuramını ortaya koymaktadır. Ona göre Cambridge değişimi (ya da bu şekilde algılandığında genel olarak değişim) her türden değişimi eş düzeye indirmektedir ancak Geach'e göre bu yanlıştır. Çünkü bazı değişimler yalnızca öznenin herhangi bir yüklemi taşıyı taşımamasından daha fazlasını içermektedir. Geach'e göre

25 Lawrence Brian Lombard, "Relational Change and Relational Changes", Philosophical Studies: An International Journal for Philosophy in the Analytic Tradition, Jul., 1978, Vol. 34, No. 1 (Jul., 1978): 63-79.

26 Kastettiği çalışması ve ilgili yer için Bkz.: Peter Geach, God and the Soul, (London: Routledge and Kegan Paul, 1969), 71-2. Ayrica benzer görüşleri için Bkz.: Peter Geach ve Robert H. Stoothoff, "What Actually Exists", Proceedings of the Aristotelian Society, Supplementary Volumes, Vol. 42 (1968): 7-30.

27 Peter Geach, Logic Matters, (Oxford: Blackwell Pub. 1973), 321. 
asıl ya da gerçek değişimler doğrudan öznedeki değişikliği işaret eden ikinci türden değişimlerdir. İkinci türden değişimler için Geach ilişkisel (relational) ve içsel olmayanlarla (extrinsic) ilgili önermeleri öne çıkartmaktadır.

\begin{abstract}
"Eğer her şeyden önce bir ilişkisel önermeyi A ve B gibi ilişkili şeyler hakkında yüklemlemeler yapar olarak ele alırsak bu durumda (doğru olsun ya da olmasın) önermeyi eğerki A hakkında yüklemleme yapan bir şey olarak alırsak A'da bu yüklemlemeye cevap veren bir edimsellik olduğunun ancak aynı (ya da mantıksal olarak eşit) bir önermeyi B hakkında bir yüklemleme olarak alırsak B'de bu yüklemlemeye cevap veren bir edimsellik olmayacağını ileri sürecek şekilde varsaymak anlamlı olacaktır. Ve somut örneklerde bunun doğruluğunun akla yatkınlığını gösterebiliriz. Örneğin 'Edith Herbert'ı kıskanır' cümlesini ele alalım: Eğer Edith Herbert'ı kıskanır hale geldiyse bu durumda bunu Herbert'taki bir değişim (onun 'kıskanılma durumuna gelmesi') olarak ele almaktansa Edith'teki bir değişim olarak düşünmek doğaldır. (...) Bu Edith Herbert'ı kıskandığında cümleye akla yatkın bir içerik verir ki bu da Herbert'in değil Ediht'in tarafında 'gerçek' bir ilişki olmasıdır." 28
\end{abstract}

Elbette Geach'in haklı olduğu bir nokta var: Değişim konusunu, her türden özelliği eş düzeyli görülerek yalnızca bir özelliğin, bir nesne ya da olay, kısaca bir özne tarafından sahip olunmas ${ }^{29}$ üzerinden tartışmak kısıtlayıcıdır çünkü o zaman şu iki durumdaki değişim aynı türden değişimler olarak görülme riskiyle karşı karşıya kalınır:

Bir felsefe konferansı esnasında gerçekleşebilecek bir durumu örnek olarak düşünürsek:

Durum 1: $\mathrm{K}_{1}$ kişisi $\mathrm{K}_{2}$ kişisinin sağ yanında oturmaktadır. $\mathrm{K}_{1}$ sıkılarak, en azından yer değiştirerek uykusunu dağıtmak ister ve yerinden kalkarak $\mathrm{K}_{2}$ 'nin sol yanına oturur. Artık $\mathrm{K}_{1}$ $\mathrm{K}_{2}$ 'nin sol yanında oturmaktadır.

$$
\begin{aligned}
& \mathrm{T}_{1} \text { anı: } \mathrm{K}_{2} \text { 'nin sol yanında } \mathrm{K}_{1} \text { vardır. } \\
& \mathrm{T}_{2} \text { anı: } \mathrm{K}_{2} \text { 'nin sağ yanında } \mathrm{K}_{1} \text { vardır. }
\end{aligned}
$$

Durum 2: $\mathrm{K}_{1} \mathrm{~K}_{2}$ 'nin sağ yanında oturmaktadır. Konuşmayı beğenen $\mathrm{K}_{2}$, sunumun başındaki uykulu durumdan çıkar ve uykusu dağılır.

28 Geach, Logic Matters, 321. Bu açıklamadaki akıl yürütmenin esasında Russell'ın İngiliz İdealistlerine karşı asimetrik bağıntılardan hareket eden argümanındaki akıl yürütmeye ne kadar benzediğine de dikkat etmek gerekmektedir.

29 Konunun şimdiye kadarki ele alınışından da ortaya çıktığı üzere tartışma doğrudan doğruya özellikler tartışmasıyla çok ilişkilidir. Dolayısıyla özellik ve nesne arasındaki ilişkinin doğasına dair birazdan ele alacağımız kuramlar bağlamında da buradaki niteleme önem kazanmaktadır. Nesnenin bir özelliğe sahip olması kadar, onu taşıması, örneklemesi, bir örneğini taşıması, örnekten pay alınması, örnekte içerilmesi, örneğin yüklemlenmesi, yüklenerek örneklemesi, örnekleyerek yüklenmesi vb. pek çok ilişkiden söz edilebilir. Biçimsel, mantıksal açıdan bakıldığında hiç farklı olmayan bu yaklaşımlar ontolojik bir kuramın ortaya koyuluşunda örneğin özellikler konusunda adcılıkla gerçekçilik arasında ya da dış dünyanın neliği bağlamında gerçekçilik ile idealizm arasında çeşitli kuramların ortaya çıkmasına neden olmaktadır. 
$\mathrm{T}_{1}$ anı: $\mathrm{K}_{2}$ uykuludur.

$\mathrm{T}_{2}$ anı: $\mathrm{K}_{2}$ uykulu değildir.

Her iki durumda yalnızca tümce bağlamında ya da dil bakımından düşünüldüğünde kesinlikle aynı şeyin yaşandığı açıktır. İlk durumda $\mathrm{K}_{2}$ sol yanında $\mathrm{K}_{1}$ 'in bulunması özelliğine sahipken, ikinci anda sağ yanında $\mathrm{K}_{1}$ 'in bulunması özelliğine sahip olur. İkinci durumda ise $\mathrm{K}_{2}$ uykuluyken ikinci anda canlı bir duruma geçmiştir. Her iki durumda da $\mathrm{K}_{2}$ bir özelliği kaybetmiş ve onun yerine başka bir özelliğe sahip olmuştur.

Ancak bir yandan da iki durum arasında apaçık bir farklılık da bulunmaktadır. $\mathrm{T}_{1}$ anındaki $\mathrm{K}_{2}$ ile $\mathrm{T}_{2}$ anındaki $\mathrm{K}_{2}$ arasındaki fark nedir diye sorsak (ya da $\mathrm{K}_{2}$ 'de yaşanan değişim nedir diye sorsak) önceliğimiz onun bizzat kendinde yaşanmış bir değişim olmasından dolayı uykulu durumdan canlı duruma geçmiş olmasını cevap olarak kabul etmek yönünde olacaktır. Dolayısıyla Geach'in, değişim açıklamalarının yalnızca mantıksal bakımdan, doğruluk değerlerine bağlı kalınarak yapılıyor olmasına eleştirisinin başka bazı gereklilikler yerine getirilmezse haklı olacağı açıktır.

Ancak Geach'in karşı çıkışında dikkate almasına rağmen önemli bulmadığı bir nokta bulunmaktadır: Değişim yalnızca kendi ifadesiyle Cambridge Değişimi olarak anlaşılamasa da, Cambridge Değişimi öncelikle her türden tüm değişimleri kapsayacak genel bir değişim ifadesidir. Geach'in karşı çıkışı olan gerçek değişimlerin bu bakış açısıyla anlaşılamayacağı yönündeki düşüncesi özellikler arasında bir hiyerarşiyi savunarak ${ }^{30}$ ya da nesne kuramları içerisinde belli bir bakış açısı içerisinde kalınarak devre dışı bırakılabilir görünmektedir. Geach özellikle ilki üzerinden söz konusu değişim tanımına karşı çıkmaktadır ancak bizce asıl belirleyici olan ikincisidir.

Genellikle tercih edilen ilk yol tartışılmaya başlandığında aslında asıl belirleyici olanın ikinci yol olduğu ortaya çıkmaktadır. Bu yazıda da şimdi bu temellendirilmeye çalışılacaktır. Bir nesne kuramı ya da kabulü olmaksızın bir özellik tartışması büyük oranda yanıltıcı olmaktadır.

\section{Nesne kuramları ve özellikler}

Şimdi özellikler arası hiyerarşinin değişim konusundaki tartışmalarda ikincil olduğuna yönelik sonuca, değiş̧im konusunda karşıt iki bakış açısının özelliklerin farklılıklarına ne şekilde bağımlı olduğunu sınayarak ulaşmaya çalışacağım.

30 "Nesne-dil kavrayışını kavramak girişimi, kişinin bir şeyin monadik ya da içsel ya da içkin özellikleri ile onun ilişkileri ya da dışsal ya da dışça yanlarının ayrımının dikkate alınması gerektiğini gösterir. Değişim konusundaki doğal görüş bir şeydeki gerçek, metafizik değişimin monadik ya da içsel ya da içkin özelliklerindeki bir değişim olmasıdır." Bkz.: Chris Mortensen, "Change and Inconsistency". 
Nesnelerin ne şekilde bireyleştikleri dolayısıyla da varoldukları ${ }^{31}$ konusunda iki farklı bakış açısı bulunmaktadır. Çağdaş ontoloji tartışmaları içerisinde yeniden ve daha incelikli olarak ele alınan bu yaklaşımlar köklerini felsefe tarihinde bulmaktadırlar. ${ }^{32} \mathrm{Bu}$ bakış açıları değişim konusunu tamamen nesne merkezli ele alıp değişimi nesne ve özellikleri ilişkisi üzerinden anlamaya çalışmaktadırlar. Aynı kaygıyı güden iki farklı bakış açısı dayanak kuramları (substratum) ve demet kuramları (bundle) olarak adlandırılmaktadır. ${ }^{33}$

Dayanak kuramları nesneyi (ed. değişen şeyi) bir dayanak (substratum) ve söz konusu dayanak etrafında özelliklerin olduğu bir bileşik olarak ele almaktadırlar. Ancak demet kuramları dayanağı saf dışı bırakarak nesneyi yalnızca özelliklerin oluşturduğu bir bileşik olarak görmektedirler. Her iki kuramda da bir nesnenin değişimini ve ona bağlı bir şekilde genel olarak değişim, özellikler ve dayanağın değerlendirilmesi üzerinden ele alınmıştır. Her iki kuram da değişimi bileşik nesnenin bazı özelliklerinin değişimi üzerinden konu edinmişlerdir. Değişim konusu aslında özelliklerin ortadan kalkması ve yerlerine yenilerinin gelmesi üzerinden tartışılmış, bu da özelliklerin öne çıkmasına neden olmuştur. Öte yandan tartışmanın içeriğine bakıldığında özellikler konusu ancak bir nesne tartışmasının içerisinde önem kazanabilmektedir.

Her iki kurama, artılarına ve eksilerine kısaca göz attığımızda değişim konusunda özelliklerin hiyerarşik biçimde ele alınması gerekliliğine yönelik bakış açısının öncelikle bir nesne tartışmasına

31 Bu ikisi yani bireyleşim (individuation) ile varolmanın (being, exist) aynı şey olup olmadığı ayrıntılı bir başka tartışmaya ihtiyaç duyar ancak bu konuyu bu yazıda özellikle dışarıda bırakıyoruz. İlerleyen kısımda zaten bireyleşim tartışma konusu olacaktır. Ancak bu ikili arasındaki ilişkiye dair genel olarak üzerinde anlaşılan bakış açısı bir nesneyi konu edinebilmemin ölçütü olarak onun bireyliği ed. özdeşliği için bir kriterimizin olması gerektiği yönündedir. Bu tartışma aynı zamanda çağdaş dönemde Russell-Meinong arasındaki tartışmadan başlayan ve Quine’ın “özdeşlik kriteri” argümanıyla devam eden ve güncel farklı ontolojik tavırların ortaya çıkmasına neden olan bir tartışmadır. "Varolmak bir değişkenin değeri olmaktır" diyen Quine değer olmayı da belirgin bir özdeşlik kriteri taşımaya bağlamıştır. Bu yolla da yeni metametafizik/metaontolojik tartışmanın belirleyicisi olmuştur. Bkz.: W.V.O. Quine, From a Logical Point of View, Cambridge: Harvard University Press, 1980, s. 15. Karş. Franceso Berto ve Matteo Plebani, Ontology and Metaontology: A Contemporary Guide, (Bloomsbury Academic, 2015).

32 Bu ayrışmanın felsefe tarihindeki kökleri değişim konusundaki ayrışmanın da köklerine değin geri gitmektedir. Dolayısıyla değişim konusu ile nesne kuramları arasındaki örtüşme zorunluluğu açıtır. Her iki bakış açısının da kaynağı olarak Aristoteles görülebilir. Aristoteles her iki bakış açısının da kaynağı olarak görülebilir. Aristoteles’in özellikle Kategoriler'de dayanak anlayışına yakın durduğu ancak Metafizik'te formu öne çıkarttığı gözetildiğinde, asıl belirleyenin özellikler olduğu dolayısıyla da bir tür demet anlayışından yanaymış gibi göründüğü dile getirilebilir. Bu kaynaktan hareket eden ve karşılıklı iki kuram olarak ortaya çıkış ise modern felsefede olmuştur. Modern felsefenin iki deneyimci düşünürünün öncelikli tartışma konusu tözün doğasıdır. Bu tartısmada Locke ne olduğunu bilmediğim bir şey olarak dahi olsa tözü kabul ederken, Hume bunu kavranılmaz bulmakta ve doğrudan doğruya demet anlayışına işaret etmektedir. Çağdaş tartışmalar da bu tartışmaların devamı olarak ortaya çıkmış görünmektedir. Büyük oranda ayırt edici yan ise mantık ve dilin tartışmalardaki belirleyiciliğidir. Bkz. J. Locke, Essay Concerning Human Understanding, ed. J. Yolton, (London: Dent, 1961). D. Hume, An Enquiry Concerning Human Understanding, ed. E. Steinberg, (Indianapolis: Hackett, 1977).

33 Loux, Metaphysics, 82. 
dayanması gerektiği ortaya çıkacaktır. ${ }^{34}$ Dolayısıyla değişim en genel olarak Cambridge Değişimi olarak ifade edilebilir ancak Geach’in de öne çıkarttığı üzere bazı özeliklerin bu tartışmadaki yeri daha belirgin olacaktır. Ancak Geach'in dile getirdiğinden farklı olarak özelliklerin hiyerarşisi ya da farkı hatta nasıl birer varolan oldukları ancak bir nesne tartışması içerisinde anlam kazanabilecek, ona ikincil olacaktır.

Genellikle demet ve dayanak kuramları şeklinde ikiye bölünerek tartışma yürütülmektedir. Biz de bu hattı bozmayacağız ancak dayanak kuramlarının özellikle tümel demeti kuramlarına yönelen eleştiriler neticesinde geliştirilmiş olması bu iki kuramın karşılıklı ele alınmasını gerekli kılmaktadır. Tikel özellik (bundan sonra trop ${ }^{35}$ ) demeti kuramları da her iki kuramın eleştirisi olarak ortaya çıkmıştır.

\title{
3.1. Dayanak kuramları
}

Önceden de belirttiğimiz gibi çağdaş tartışmaların kökleri felsefe tarihindeki tartışmalardadır. Bunun en canlı örneği C. B. Martin'dir. Martin kendi dayanak kuramını Locke’un düşüncelerinin yeni bir yorumunu sergileyerek geliştirmiştir:

\begin{abstract}
“Locke bazen töz (substance) sözcügünü 'nesne' anlamında kullanmıştır. (...) Aynı zamanda bazen de töz (substance) sözcügünü 'dayanak (substratum)' anlamında kullanmıştır. (...) Burada araştıracağım Locke’un 'töz' terimini kullanım yorumu, 'dayanak' terimi ile değiştirilebilir bir kullanım olacaktır."’36
\end{abstract}

34 Bu nedenle özelliklere ilişkin kuramlarla beraber düşünüldüğünde "nesne nedir?” sorusuna cevap olarak genellikle iki öbekte toplanan dört kuramın geliştirilebileceği ortaya çıkmaktadır. Biz burada özellikle üçü bağlamında tartışma yürüteceğiz. Aslında özelliklerin ele alınışı ile beraber düşünüldüğünde şöyle bir tablo ortaya çıkmaktadır:

1) Dayanak kuramları:

-Nesneler, bir dayanak ve tümellerin birlikteliğidir.

-Nesneler, bir dayanak ve tikel özelliklerin (trop) birlikteliğidir.

2) Demet kuramları:

-Nesneler, tümel özellik demetleridir.

-Nesneler, trop demetleridir.

Armstrong da bunu bir tablo halinde ortaya koymuştur. Bkz. D. M. Armstrong, Universals: an opinionated introduction, (London: Westview Press, 1989), 63. Aynı sınıflamayı daha ziyade demet kuramları içerisinde kalarak ele alan bir yaklaşım için Bkz.: Howard Robinson, "Substance", The Stanford Encyclopedia of Philosophy, ed. Edward N. Zalta, erişim: 16.11.2020, URL = <http://plato.stanford.edu/archives/spr2014/entries/substance/>.

35 Tropların pek çok farklı biçimde dile getirildikleri sıklıkla vurgulanmaktadır. Armstrong trop terimini tereddüt ile kabul ettiğini bildirmiştir. Ona göre bunun nedeni ortada aşırı bir adlandırma çeşitliliğinin bulunmasıdır: “Trop terimini biraz tereddüt ile benimsedim. Sorun isim azlığından dolayı değil ancak aşırı isim fazlalığı dolayısıyladır. Bence olan şey, pek çok durumda tropların filozoflarca yeniden keşfedile gelmesinden kaynaklandı. Bu durumda kuramın çoktan eski ve saygı duyulacak bir kuram olduğundan habersiz bir şekilde her bir filozof onlar için yeni bir isim uydurmuştur. Böylece "soyut tikeller” (Stout 1921, Campbell 1981), "mükemmel tikeller” (Bergmann 1967), "troplar” (D. C. Williams 1966), "durumlar” Wolterstorff 1970), "somut tikeller” (Küng 1967 -tümelleri soyut özellikler olarak adlandırmıştır--), "birim-özellikler (Matthews and Cohen 1968), "özellik-örnekleri” (çeşitli filozoflar) gibi kavramlarımız vardır. Trop terimi biraz daha tutmuştur bundan dolayı Williams’ın kavramını takip etmeye karar verdim." Armstrong, Universals, 113. Biz de bu bağlamda, belli anlam yüklerinden ayrı düşünülebilmesine olanak vermesi açısından trop kavramını kullanacağız.

36 C. B. Martin, "Substance substantiated”, Australasian Journal of Philosophy, 58:1, (1980), 3. 
Martin'e göre Locke’un kullanımından hareketle bir nesne, dayanak ile özelliklerin bir aradalığı olarak görülmelidir. ${ }^{37}$ Böylece örneğin 'araba mavidir' tümcesi 'araba mavilik özelliğini taşıyan bir çıplak tikel ile mavilik özelliği bir aradalığıdır’ tümcesine çevrilmiş olarak ele alınmalıdır:

"Bir nesne yalnızca bir özellik grubu değildir çünkü özelliklerin kendileri gruplanacak nesneler değillerdir. Bu durumda bir nesne, bir içerik olarak yalnızca bir özellikler kümesi ihtiyacı ile bulunmaz ancak aynı zamanda taşınması gereken özellikler nelerse o özelliklerin taşıyıcısını da içerir." 38

Bir çıplak tikel ihtiyacının özellikle nesnenin bireyleşimi (individuation) ve özdeşliği sorunlarının çözümü bağlamında ortaya çıktığı görülmektedir. ${ }^{39}$ Allaire’e göre bir tekille (individual) karşı karşıya kaldığımızda iki tavır geliştiririz. Onu ya 'tikeller toplamı' olarak görürüz ya da 'tümeller toplamı' olarak görürüz. Allaire ilk kuramın iki diskin aynılığını açıklayamayacağını çünkü özelliklerin aynılığının garanti altına alınamadığını öne sürer. ${ }^{40}$ Diğer tavırda da diskler, tümellerin ${ }^{41}$ bir toplamı olarak görüldügüünden aynı tümelin örneklenmesinden dolayı tamamen aynı özelliklerden oluşmuş iki arabanın nasıl bireyleştikleri ortaya konamaz. ${ }^{42}$

"Birey-karakter incelemesi (analysis) her iki itirazla da karşılaşmaz. Gücü buradadır. Disklerin farklılığı her birinin farklı bir birey içermesi ile; aynı oluşları ise her birinin tam olarak aynı karakterleri içermeleriyle (...) açılkanır. Bireykarakter analizi en azından 'şeylerle' bağlantılı bir biçimde ortaya çıktığında aynılık ve farklılık sorunlarını çözmeye izin verir. Daha geleneksel biçimde dile getirilirse, adcılık-gerçekçilik konusuna bir çözüm önerir.”ł3

37 Bkz.: Martin, "Substance substantiated”, 6. Deneyim bağlamında bakıldığında da kişi aslında iki şeyi deneyimlemektedir. Allaire’nin aktardığına göre örneğin Bergmann "Başka bir şey olmayan, bir kırmızı leke ile kişi tanıştı̆̆ında, tek bir şeyle değil, iki şeyle karşı karşıyadır, bir tikel (...) ve bir karakter” demektedir. Bkz.: Edwin B. Allaire, "Bare Particulars", Philosophical Studies: An International Journal for Philosophy in the Analytic Tradition, Vol. 14, No. 1/2 (Jan. - Feb., 1963), 2.

38 Martin, "Substance substantiated", 7.

39 Bergmann Realism adlı eserinde bireyleşme sorununun çözülebilmesi için niteliklerin (e.d. tümellerin) kullanılamayacağını, sorunun çözümü için gerekli olanın bir çıplak tikel olduğunu dile getirmiştir. Bergmann’ın kuramı yazı içerisinde detaylı ele almadığımız sınıflamada geçen haliyle dayanak ve tümellerden nesneyi oluşturan diğer kuramdır. "Yalın tikeller ne doğadırlar ne de doğaları vardır. Bu durumda herhangi iki tanesi içsel olarak (intrinsically) değil sayısal olarak farklıdırlar. Bu da onların çıplaklıklarıdır. Bir çıplak tikel için birden çok 'şeyde' olması imkânsızdır. Bu da onların tikellikleridir. (...) Bu alternatife göre olağan bir şeyin içindeki şeylerin hepsi aynı kategoriye dahil değildirler. Biri bir çıplak tikeldir, tüm diğerleri de niteliklerdir. (...) Bir çıplak tikel yalnızca bireyleştiricidir. Yapısal olarak bu onun tek işidir. Başka bir şey yapmaz." Gustav Bergmann, Realism: a critique of Brentano and Meinong, (Madison: University of Wisconsin Press, 1967), 24-5.

40 Allaire, "Bare Particulars", 2.

41 (Bergmann tümellere 'karakterler' demektedir.)

42 Bkz.: Allaire, "Bare Particulars", 3. Allaire'in burada eleştirdiği kuramları birlikte ele alabilmek için biz bu tartışmayı sonraki başlığa bıraktık. Onu kastettiği iki kuram tümeller demetleri kuramları ve tikeller demetleri kuramlarıdır, bunlarla ilgili tartışmalar ve Allaire'nin argümanın detaylarını sonraki başlıktaki tartışmalarla karşılıklı değerlendirmek gerekmektedir.

43 Allaire, "Bare Particulars", 3. 
Allaire'e göre içsel olarak (intrinsicially) farklı olmak karakterler arası bir durumdur, oysa çıplak tikeller sayısal bakımdan farklıdırlar. ${ }^{44}$ İki çıplak tikelin bireyleştirmek dışında bir görevleri yoktur: "Bireyler ${ }^{45}$ yalnızca tüm bakımlardan (ilişkisel olmayan) aynı olan iki şeyin sayısal farklılığını temellendiren varolanlardır.”46

Böylece her iki durumda da bir tikellik ile karşı karşıya olduğumuz anlaşılmaktadır. Ancak bu bakış açısı bir sorunu ortaya çıkarır: Çıplak tikelle deneyimde nasıl karşı karşıya olunacaktır?

Dayanak kuramlarına göre ne özellikler ne de taşıyıcı kendi başlarına herhangi bir şey değillerdir. Ancak her ikisi de nesne hakkında bir şeylerdir:

"Dayanak özelliklerin taşıyıcısı olan nesne hakkında bir şey olacaktır. Hangi özellikleri dayanağın taşıdığı, dayanak olarak dayanağın ne olduğunu belirlemeyecek ancak nesnenin ne tür olduğunu belirleyecektir. Nesne olarak nesne hem özelliklerin taşıyıcısı hem de taşınan özelliklerdir. Böylece o yalnızca gerçek dayanakların ('küçük' d) ya da bireysel şeylerin değişik türleri olmayı kabul edecektir." ${ }^{\prime 4}$

Böylece Martin'e göre dayanak tek başına da bulunamaz. Nasıl ki nesneler özelliksiz var olamazlar çıplak tikeller de özelliksiz var olamazlar. Çıplak tikeller de nerede bir nesne varsa oradadırlar ve özelliklerle birliktedirler. ${ }^{48}$

Martin dayanağın varlığına dair yöneltilen bir eleştiriyi cevaplayarak bir başka argüman daha ortaya koyar. Martin’e göre böyle bir dayanağa ihtiyaç duymamızın nedeni, dilimizin özneyüklem yapısında da (ve mantıkta niceleme durumunda) görülebilir. ${ }^{49}$

Bir dayanağa duyulan ihtiyacın bir başka kanıtı da nesnelerin yalnızca özellik toplamları olarak (demet) görülememesinden üretilmeye çalışılmaktadır. Ancak bu eleştirinin ağırlıklı olarak tümel demetlerini hedef aldığı açıktır çünkü tümel demetleri kuramlarının en zayıf yanları (Allaire'in belirttiği gibi) tamamen ortak özelliklere sahip iki nesnenin özdeş olmalarına rağmen nasıl olup da sayısal olarak ayrı görüleceğinin bilenememesidir:

"Locke özellikleri bir tür soyut, Platoncu tümeller olarak düşünmedi. Diğer türlü,

O ve Hume belli bir nesnenin yalnızca bir özellik grubu olup olmadığı konusunu

zorlukla tartışırlardı. 'Şekil'in Lockeçu anlamında örneğin, dairesel şekillerin

44 Bkz.: Allaire, "Bare Particulars", 6.

45 Allaire çıplak tikel yerine bireyler (individuals) demektedir.

46 Allaire, "Bare Particulars", 6.

47 Martin, "Substance substantiated", 7.

48 Bkz.: Martin, "Substance substantiated”, 8. Ancak bu görüş elbette eleştiri alacaktır çünkü bu yapıda olmayan dillerin de olduğu öne sürülebilecektir. Martin böyle bir durumda bile kuramının savunulabilir olduğunu düşünmektedir çünkü böylesi dillerin olduğu kanıtlanmış bir olgu değildir. Ayrıca bu dillerin varlığı doğru olsa bile, bu durum kuram için bir sorun yaratmamaktadır: "Çünkü ikinci olarak, eğer bazı diller bir dayanak öne sürüyorsa ve bazıları sürmüyorsa 'Hangisi doğru?’ sorusu hâlâ ortaya çıkmalıdır. Bu durumda dayanak için ve alternatif kuramlara karşı argümanlar göz önüne alınmalıdırlar." Martin, "Substance substantiated”, 9.

49 Martin, "Substance substantiated", 8. 
sayısını sayabiliriz -biri burada ve diğeri orada şeklinde. Ve Hume özellikleri demetlendirdiği zaman, onun burada demetlendirdiği dairesel şekil ile orada demetlendirdiği dairesel şekil sayısal olarak özdeş değildir.-"

Böylece Martin’e göre tikel özellikler görüşünde iki şey aynı olabilir: Benzer tikel özellikler taşımaktadırlar. Ancak yine de bu yeterli değildir. Bireyleşmeye yine de özelliklerin ilişkili olduğu bir dayanak yol açmaktadır.

Dayanak kuramlarının en güçlü oldukları yan açıktır ki değişen bir nesnenin tüm özelliklerini değiştirdiği durumda bile özdeşliğini savunabilmelerinden kaynaklanmaktadır. Ancak bu olumlu yan aynı zamanda bu bakış açısının zayıflığını da getirir çünkü bu durumda klasik olarak tözsel değişim olarak adlandırılmış değişim, yani kökten değişim açıklanmamış olarak kalır.

Dayanak kuramları ikinci olarak her şekilde yalnızca özellikleri ile tanımlanmış bir nesnenin varoluşunda bir çıplak, özelliksiz varolanın nasıl tanımlanabileceğinin de açıklamasını verememektedir.

Üçüncü olumsuzluk ise doğrudan değişim konusundadır. Değişim söz konusu olduğunda biz öncelikli olarak özellikleri ikinci olarak özellikler içinde özel bazı özellikleri öne çıkarırız. Bu da bir dayanağı her zaman nesneye, uzam-zaman bölgesine, özelliklere veya bir duruma (olay) ikincil olarak konumlandırırız anlamına gelmektedir. Dolayısıyla kökensel olduğunu ileri sürme olanağımız ortadan kalkmaktadır.

Denkel'e göre tümellerden oluşan demet kuramı başarılı olmadığından dayanak kuramları öne çıkmıştır. Tümeller başarılı bireyleştiriciler olmadığından dayanak arayışı söz konusudur. Oysa tikelcilik bunu başarılı bir biçimde gerçekleştirmektedir dolayısıyla dayanağa ihtiyaç duymamaktadır. ${ }^{51}$

Denkel'in bu iddiasında da içerildiği üzere nesne kuramlarında bir diğer güçlü kuram demet kuramlarıdır ve şimdi ele alacağımız bu kuramlarda hem Denkel’in iddiasını hem de kuramları tartışma olanağı bulacağız.

\subsection{Demet kuramları}

Demet kuramları tikelleri yalnızca özellik toplamları olarak gördüklerinden bilinmeyen bir dayanağa da ihtiyaç duymamaktadır. Ancak yalnızca özellik toplamı olarak nesneleri ele aldıklarından değişim konusunda ve özdeşlik konusunda kimi sorunları aşmak durumundadırlar. Demet kuramları özelliklerin tümeller ve troplar olarak ele alınmasına bağlı olarak tümel demet kuramları ve trop demetleri kuramları olarak iki biçimde savunulmaktadır.

50 Martin, "Substance substantiated", 7.

51 Bkz.: Arda Denkel, "Substance Without Substratum”, Philosophy and Phenomenological Research, Vol. 52, No. 3, (Sep., 1992), 705. Bu görüşün haklılığı tümel demeti kuramlarının incelenmesinde ortaya çıkacaktır. 


\subsubsection{Tümel demet kuramı}

Demet kuramlarından ilki büyük oranda etki gücünü kaybetmiş görünen ve Russell tarafından savunulmuş bir kuramdır.

Russell'a göre tümeller yekpare birlikli yapılarını koruyarak nesne oluşturmaktadırlar.

“ 'bu kırmızıdır'ın bir özne-yüklem önermesi olmadığını, ancak 'kırmızılık buradadır' biçiminde olduğunu; bu 'kırmızı'nın bir ad, yüklem olmadığını; ve böylece genellikle bir 'şey' olarak adlandırılanın; kırmızılık, sertlik vb. gibi eş bulunuşlu niteliklerin bir demetinden başka bir şey olmadığını önermek istiyorum." ${ }^{52}$

"Fizik için bir şey, kesintisiz bir uzam-zaman bölgesini işgal etmiyorsa 'şey’olarak sayılmaz oysa kırmızılık böyle değildir. (...) amacımız da niteliklerden, fiziğin 'şey’ler için gereksindiği uzam-zaman özelliklerine sahip demetler inşa etmektir."’33

Russell’a göre "Bu gül kırmızıdır" dendiğinde:

“'bu’ belli uzamsal nitelikleri gösterir (niteliklere gönderimde bulunur-y.n.) (...). 'Gül' sözcüğü bir nitelik demetini belirtir (...). 'kırmızı' sözcüğü bazı güllerde olan diğerlerinde olmayan bir niteliği belirtir." ${ }^{34}$

Dolayısıyla da aslında töz gibi bir şey düşünüyor oluşumuz bir yanılgı sonucudur. Eğer nitelikleri bakımından iki şey aynı ise biz bunları hiçbir biçimde ayırt edemeyiz. Hangisinin hangisi olduğunu belirleyemeyiz:

"Eğer bir insanda tözün maddi özdeşliği olsa bile bu algılara açık olmayacaktır (...) biz insanı onun kişisel deneyiminin önceki kişisel deneyimlere olan benzerliği ile anlarız, yani, niteliklerin benzerliği ile. Tözün özdeşliği var mıdır yok mudur sorusu metafizikçi için bir sorudur ve boşuna bir sorudur çünkü her iki yönde de bir kanıt yoktur." 55

Gördüğümüz üzere Russell dayanak kuramlarının öne çıkarılmasına yol açan tutumu dışarıda bırakmaktadır. Bununla birlikte tümel özelliklerden oluşmuş iki nesnenin nasıl ayrımlanabileceği konusunda bilinemezci bir tutum takınmaktadır. Ancak bu kuramın en çok eleştirilen yanı da bu tutumdan kaynaklanmaktadır.

Kuramın en zayıf noktası tamamen aynı tümel özelliklerden, özelliklerin bir aradalığı ilişkisi ile kurulmuş olduğu düşünülen bir tikel ile tamamen aynı tümellerden oluşmuş bir başka tikelin

52 Bertrand Russell, An Inquiry Into Meaning and Truth (London: George Allen\&Unwin Ltd, 1956), 97.

53 Russell, An Inquiry Into Meaning and Truth, 100.

54 Bertrand Russell, "The Problem of Universals", Russell on Metaphysics: selections from the writings of Bertrand Russell içinde, ed. S. Mumford (London: Routledge, 2003), 152.

55 Russell, "The Problem of Universals", 149. 
ayrımlanması sorunundan kaynaklanmaktadır. Bu Ayrılamazların Özdeşliği İlkesiyle bir biçimde hesaplaşılmasını şart koşar: Ya ilke yanlış olacaktır ya da nesnenin bireyleşimine dair bir açıklama verilecektir. Bu konunun ele alınabilmesi için Black’in, tamamen aynı iki küreden başka hiçbir şey olmayan bir evrenle ilgili düşünce deneyindeki iki kürenin sadece nitelikler göz önüne alınarak ayrımlanamıyor oluşuna ilişkin argümanına bakmak gerekmektedir. ${ }^{56}$ İki şeyin ayrımlanamıyor olduğu özellikler makalede geçtiği üzere şunlardır:

"Mavi, katı, tatlı vb., aynı şekil ve ölçüler, evrendeki her şeye aynı ilişkiler (...) demirden yapılmak, bir mil çapında olmak, sıcaklık, renk vb. (...) birbirinden belli bir uzaklıkta olmak, kendiyle bir uzaklıkta olmamak, (...) kendiyle aynı yerde olmak gibi ilişkisel nitelikler (characteristics). ${ }^{37}$

Yalnızca iki kürenin olduğu, bir gözlemcinin ya da sistem dışında bir duruş noktasının belirlenemediği böyle bir evrende sol-sağ (gözlemciye bağlı olacağı için) kürelere ad verme, (bir gözlemci varsayacağı için) ya da bir başka nesnenin olması engellendiğinde (çünkü asimetrik ilişkiler ortaya çıkabilir) geriye sadece iki kürenin nitelikleri yoluyla ayrımlanma olanağı kalır. Ancak bu sefer de bir kürede olan her bir özellik tamamen aynısı olan diğer kürede de olacağından iki küreyi ayrımlayacak herhangi bir fark bulunamayacaktır. Böyle bir düşünce deneyinin özellikle tümel demetleri kuramları için bir zorluğa işaret ettiği açıktır.

\subsubsection{Trop Demeti kuramlari}

Trop demeti kuramları nesneyi oluşturmak açısından tümel demeti kuramlarıyla örtüşmektedir. Ancak tümel demeti kuramlarından özelliklerin tikel olması ve kendiliğinden bireyleştirici olmaları bakımından ayrılmaktadır.

Campbell'e göre bir somut nesne için o nesnenin tropları bağlamında şu söylenebilir: "Bir elmas düşünün. Elmasların trop kuramı bir demet kuramıdır. Bu elmas tropların e.d. niteliklerin tikel durumlarının eş-bulunuşlu (compresent) bir demetidir." ${ }^{58}$ Her türden özellik trop kuramında içerilmektedir ve hepsi tikellerdir.

Trop demetleri kuramları demeti troplar üzerinden tanımlarlar. Dolayısıyla tikel özellikler arasında bir özdeşlik varsayılmadığından Black’ in makalesinde öne sürdüğü türden bireyleşimin gösterilememesi gibi bir itirazla karşılaşmazlar. İki demet, farklı tikel özelliklerden oluştuğu için bu iki demetin özdeşliğinden söz edilemez. Her biri örneğin bir diğerinden ayrı tekil bir kırmızı taşımaktadır. ${ }^{59}$ Bunun yanı sıra elbette troplar arası ilişkinin de açıklanması gerekmektedir. $\mathrm{Bu}$ ilişki de genellikle benzerlik üzerinden sağlanmaktadır. Bir trop aynı türden bir diğer tropa az ya da çok benzerdir.

56 Max Black, “The Identity of Indiscernibles”, Metaphysics: contemporary readings içinde, ed. M. J. Loux (NY: Routledge, 2005), 104-114.

57 Black, "The Identity of Indiscernibles", 107-8.

58 Keith Campbell, Abstract Particulars (Oxford: Basil Blackwell Ltd., 1990), 20.

59 Bkz.: Campbell, Abstract Particulars, 21. 
Trop demeti kuramları tek kategorili ontolojik kuramlardır. Bundan dolayı özne-yüklem bağlantısı dolayısıyla özellikleri ‘bir nesnenin özellikleri’ olarak görme eğilimindeki, nesne ile özellikleri birbirinden ayrı gören kuramların hepsini yanılgı içinde görür. Eğer troplar tek geçerli yalın varolanlar ise bu durumda bir nesne hakkında şunlar dile getirilebilir:

"Ancak somut tikeller türetilmiş kompleks varolanlardır. Sertlik, katılık, ısı vb. olmaksızın bir elmas olmaz: bağımlılığın bu yönü kesin biçimde ontik durumu yansıtmaktadır. Bir olağan nesne, bir somut tikel, eş-bulunuşlu tropların toplam grubudur. Böyle bir toplam grup olmasıyla kendi yerini tekeline alır (monopolize) tıpkı olağan düşünüşte olağan nesnelerin yaptığı gibi." ${ }^{00}$

Böylece klasik ontolojilerde nesne (dilsel karşılığı ile özne) birlikli varolanı bir trop bir aradalığı olarak düşünülmelidir. Klasik töz görüşünü eleştiren Campbell'e göre bir töz anlayışından da söz edilemez. Tikel demetleri töz yerine geçtiğinden olağan düşünüşte töz olarak görmeye eğilimli olduğumuz nesneleri de bu şekilde düşünmememiz gerektiği ortaya çıkar. Ona göre özellikle filozoflar böylesi gündelik bir bakış açısını kabul etmek zorunda değillerdir. ${ }^{61}$

Klasik özne-yüklem ilişkisi üzerinden kurulan bir ontolojide, yine yüklemlerin karşılığı olarak görülme eğiliminde olunan tümeller de (trop kuramı sayesinde) doğallığında reddedilmektedir. Özneye bir tikel varolanın denk düşmesi beklentisi kadar, yükleme de bir tümelin karşılık gelmesi beklentisi yanıltıcıdır. ${ }^{62}$ Tikel özelliklerin benzemelerinin bir ontoloji için kökensel ve yeterli olduğu ortaya konur. Bireyleşim konusunda da kuramın başarısı klasik töz görüşünün başarı iddiasıyla gerekçelendirilir: "Eğer tözler bunu yapabiliyorlarsa, troplar neden yapamasınlar?”63 Campbell trop biraradalığını eşbulunuş olarak adlandırır. ${ }^{64}$ Tropların bir aradalığı için "bir kökensel bağ düşünülecekse bunun için en doğal adayın eş-bulunuş (compresence) olması" gerektiğini dile getiren Campbell; "pek çok tropun olağan somut tikelleri sağlamak adına birleşebileceklerini”"65 ileri sürmektedir.

Tropların tikellikleri bir bakıma uzam-zamansal tikelliğe de gönderim yapar. Ancak konuma yapılan gönderim, ikincil bir konudur. Tropların kendileri tikel varolanlar olduklarından, uzamzamansallıktan bağımsız olarak da bir demeti bireyleştirirler. Bireyleşimin kendisi ise trop kuramı açısından temel (türetilmemiş) ve analiz edilemez bir şeydir. ${ }^{66}$ Trop kuramı böylece ne çıplak dayanağa ne varolmalarının kurama ne kattıklarının belirlenemediği tümellere ne de klasik anlamda tözlere gereksinir.

60 Campbell, Abstract Particulars, 21.

61 Bkz.: Campbell, Abstract Particulars, 10.

62 "İlk bakışta konu tamamen ontolojiktir. Dünyadaki nesnelerle ve onların birbirleriyle paylaştıkları özelliklerle ilgilenir. Tümeller sorunu ise ikincil olarak yalnızca semantik bir konudur." Campbell, Abstract Particulars, 28.

63 Campbell, Abstract Particulars, 57.

64 Trop ya da tümel demeti bir aradalıkları çeşitli düşünürlerce farklı kavramlarla da dile getirilmiştir. Russell eş-bulunuş (compresence), Williams eşkonumluluk (collocation) ilişkisini kullanır. Bunların yanısıra Loux'un aktardığına göre Herbert Hocberg bileşimi (combination) önermekte, Castaneda da eştözselleşme (consubstantiation) veya eşaktüellik (co-actuality) ilişkisini kullanmaktadır. Bkz.: Michael J. Loux, Substance and Attribute: a study in ontology (Holland: D. Reidel Pub. Com., 1978), 122-3.

65 Campbell, Abstract Particulars, 58.

66 Bkz.: Campbell, Abstract Particulars, 69. 
Bunun yanı sıra tümel demetleri kuramlarının yaşadığı sorun, belli bakımlardan trop demetleri kuramları için de geçerlidir. Her ne kadar iki demet tikel özelliklerden oluşmuş olmaları bakımından kendi bireyselliklerine sahiplerse ve bundan dolayı Ayrılamazların Özdeşliği İlkesi ile bir sorun yaşamasalar da uzam-zamanın bir trop olarak sisteme dahil edilme riski bulunmaktadır. Böyle bir zorunluluğun demetin değişiminde bir trop kaybedildiğinde nasıl bir açıklama verileceğine etkisi bulunmaktadır. Yani trop demeti kuramları, eşzamanlı bir özdeşlik sorunu yerine (tümel demet kuramlarının başında geldiği gibi) zamanlararası bir özdeşlik sorununu çözmek zorundadır.

Trop demet kuramlarına bir başka itiraz, kuramın töz görüşünü tam anlamıyla devre dışı bırakamaması öne sürülerek yapılır. Loux oluşturucu olan tikel özellikler düşüncesinin baştan kurulu bir töz varsayıldığı durumda demete yol açabileceğini dile getirmektedir. Oluşmuş bir varolan olarak demet, neyin oluşacak olmasıyla tikel özelliklerin bir araya getirilmesine yol açar ki bu da demetlerin özelliklerine özsel olarak sahip olmalarına yol açar. Böylesi bir anlayışın da demetin değişimini açıklayamayacağı açıktır. Demetteki tüm özellikler özsel ise demet değişmemek zorundadır. Diğer bir deyişle tek bir özelliğin ortadan kalkması yeni demetin eski demetten farklı olması sonucunu doğurur. ${ }^{67}$

Bu durumda tikel özelliklerle, oluşturdukları öne sürülen demetler arasında bir kısırdöngü ortaya çıkar. Lowe burada bir kısırdöngünün belirdiğine, "arabayı atın önüne koşmak" ${ }^{6}$ şeklinde ifade ederek değinir:

"Yani bu, tropların kendilerinin en azından kısmen de olsa ait oldukları tözlerle bireyleştiklerinde ısrar etmek olabilir - bir tikel kırmızlık yani onun özelliği olduğu kırmızı tikel nesne tarafından [bireyleşir].- Bu her durumda o kişiyi ölümcül bir döngüye sokacaktır yani bireysel tözün de sırasıyla troplarıla bireyleştiğini söylemek gibi." ${ }^{69}$

Değişim demetten bir tropun ayrılmasıyla ortaya çıkacaktır. Ya tekellerine aldıkları konumun ya da konum aynı kalmakla beraber özelliğin değişmesi gerekecektir. Ancak eşbulunuş 'o özellikler'le bir demeti imliyorsa, demetteki trop değiştiğinde özdeşlik nasıl savunulacaktır? Her trop değişimi ayrı bir demeti ortaya çıkaracaktır.

Bir diğer eleştiri de şu şekilde sergilenebilir. a, b, c, d, troplarının bir araba demeti oluşturması tüm troplar içerisinde araba tropunun öne çıkmasına yol açacaktır. Hatta 'o araba' gibi bir trop en önemli trop haline gelecektir. Dolayısıyla tek bir şeyin özdeşliğini (eğer varsa) açıklamakta troplar arasında ayrım gözetilmezse değişim konusu açıklanamaz kalacaktır.

67 Bkz.: Loux, Substance and Attribute, 133.

68 E. J. Lowe, "Individuation", The Oxford Handbook of Metaphysics içinde, ed. Loux\&Zimmerman (Oxford: Oxford University Press, 2003), 83.

69 Lowe, "Individuation", 83. 


\title{
4. Değişimi yeniden değerlendirmek
}

Demet kuramlarının genel olarak benzer bir noktada sıkıştıkları görülmektedir. $O$ da değişim karşısında demetin aynılığının garanti altına alınmasında yaşanan zorluktur.

\begin{abstract}
"Her ne kadar yeni görüş bir şeyi, özellikler kompleksi olarak bileşenleri eşörneklendiğinde varolan olarak tanımlasa da; görünen o ki o da diğerleri gibi bir baskıya maruz kalır. Öncelikle ilk itiraz değerlendirilsin: Demet kuramcısının dünyasında bir türden pek çok değişim yani özelliklerin ilişkisel niteliklerindeki değişim olduğu doğrudur; verili bir özellik ya da onların bir grubu şimdi bir özellikle şimdi de bir başkasıyla eş-örneklenmiş olabilir. Ancak bu herhangi bir bireysel değissebilir demek değildir. Eğer $F$ ve $G$ önce $H$ ve sonra $K$ ile eşörneklenmişse, kompleks FGK kompleks FGH'nın yerine geçer, elimizdeki tek şey bir bireyin başka bir birey ile değişmesidir, yoksa aynı ve bir bireyin özelliklerindeki değişim değildir. FGH, FGK ile yalın biçimde özdeş değildir." ${ }^{\text {70 }}$
\end{abstract}

Bu sorun demet kuramlarını farklı araçlarla da olsa tek bir çözüme odaklanmaya götürmüştür. Bu çözüm özellikler arasında hiyerarşik farklılıklar koymaktır.

Bu sonuca iki araştırmadan geçerek vardık: Birinci olarak değişimin tanımı bağlamındaki tartışmadan hareket ettik ve burada değişen şeyin kendisinin anlaşılmasının gerekliliğini gördük. İkinci olarak da dayanak ve demet kuramlarını tartıştık. Tanımdan kaynaklı olarak özne yerinde duran değişen şeyin dikkate alınması yönünde bir eleştiri ile karşılaştık. Geach gerçek değişimleri nesnede bir değişiklik yapan (içsel özellikler) üzerinden ele alıyordu. Ancak bu sonucun bir nesne kuramı ortaya koymadan geçerli bir sonuç olduğunun söylenemeyeceği ortaya çıkmıştır. Özne yerinde duran terimin gönderim yaptığı varolan nasıl bir varolandır ve yüklem yerinde duran kavramın gönderimi olan ilgili özellikle ne şekilde ilişkilidir? ${ }^{71}$ İkinci soruşturmada da demet kuramları içerisinde nesnenin özelliklerden oluşmasının bu kuramları doğallığında tek biçimli bir açıklama vermeye yönlendirdiği görüldü. Ancak bundan elbette ilgili kuramların her türden değişimi aynılaştırdığı yönünde bir eleştiri çıkmaz.

Her türden değişimin öznenin ya da klasik anlamda tözün başına gelen bir şey olduğunun ileri sürüldügünün savlandığı ve bunun gerçek değişimler ile gerçek olmayan değişimleri birbirine karıştırdığı iddiası ile karşı karşıyaydık. Oysa yaptığımız araştırmada şu nokta açıklığa kavuşmaktadır: Değişim klasik anlamda tözsel bir olgu olarak görüldüğünde ilgili yanlış anlamanın

70 James Van Cleve, “Three Versions of Bundle Theory", Metaphysics: contemporary readings içinde, ed. M. J. Loux (NY: Routledge, 2005), 124.

71 Tüm bu tartışmanın yaptığımız alıntılarda ara ara görünür olan semantik bir yanı vardır ve özellikle dil felsefesi bağlamında yoğun tartışmalara neden olmuştur. Bu tartışma gönderim sorunu olarak ifade edilebilir. Bu tartışmaya özel olarak girmedik ancak hem Campbell'in hem de Russell'ın her zaman bu yanı akılda tutarak kuramlarını geliştirdikleri açıktır. Örneğin Russell'ın demet kuramından yana olmasının nedeni aslında Gönderim $\ddot{U}$ zerine makalesinde özel adlar ve belirli betimlemeleri doğrudan gönderim yapmayan dilsel ifadeler olarak konumlandırmasından kaynaklanmaktadır. Bkz. Bertrand Russell, "On Denoting”, Mind ,114, no. 456 (2005): 874 . 
ortaya çıkma olasılığı vardır. Ancak, hem taraflardan Russell'ın hem de bu geleneğin devamcısı tikel demeti kuramlarının klasik anlayışın dışında oldukları ortaya çıkmaktadır. Her iki yaklaşım da, dilsel yapının değişim olgusunun anlaşılmasında insanı yanıltıcı bir yanı olduğundan hareket etmektedir. Dolayısıyla asıl yapılması gereken özne konumunda bulunan tikelin tözsel bir varolan olduğu yanılsamasından kurtulmak adına, onu özelliklere çözümlemektir.

Tam da bu sayede özellikler arasında bir hiyerarşi ihtiyacı kendini gösterecektir ancak bu kökensel bir fark olmayacaktır. Yani her türden belirlenim bir özellik olacak ama bunlardan bazıları demetin merkezinde bulunacaktır. $\mathrm{K}_{1}$ ve $\mathrm{K}_{2}$ 'nin değerlendirildiği örneği düşündüğümüzde her iki durum için demet kuramlarının önerdiği çözüm şu şekildedir:

'...özelliklerinden oluşmuş demette ... özelliği vardır.'

Özne konumundaki tikel özelliklere indirgendiğinde tek bir şeyin başına gelen bir şeyden de söz edilemeyeceği için doğallığında bütün değişim türlerinin aynılaşmasının önüne geçilir çünkü aksi durumda değişim açıklanamayacaktır. Oysa Geach'in sunduğu çözümde gerçek değişimin belirlenebilmesi için somut bir varolana dikkat kesilmemiz gerekiyordu. Burada o tözsellik ortadan kaldırıldığında geriye kalan “... özelliği””nin ne türden bir özellik olduğu ve ilgili demetin içerisinde demetin varoluşuna ne türden bir katkı yaptığının belirlenmesi öne çıkar. Her ne kadar tümel demetini savunuyor olsa da Russell'dan alıntıyla söylersek:

“Pek çok uzam-zaman önermesi yani 'Sokrates eğri burunludur' gibiler, yüklemce adlandırılan belli bir niteliği ileri sürer ve öznece adlandırılan bir nitelik demetini ileri sürer bu demet eş-bulunuş (compresence) ve nedensel ilişkiler bakımından bir birliktir. Olağan anlamında özel adlar, eğer bu doğruysa, yanıltıcıdır ve yanlış bir metafiziği somutlaştırırlar." ${ }^{22}$

Dolayısıyla aslında demet kuramlarının yanlış bir metafizikten kurtulmak yolunda attığı adımların başka bir tartışmaya yol açtıklarını yani özellikler arası bir hiyerarşinin nasıl kurulacağının belirlenmesinin gerektiğini görüyoruz.

Şimdiye kadar özelliklerin neler olduğu üzerinde durulmadı çünkü asıl olarak bir başka sorun çözülmeye çalış1lıyordu. Ancak şimdi bir anlamda Geach'in ileri sürdüğü noktaya geldik. Özelliklerden bazıları özne yerinde duran şey açısından daha da önemli ancak bunu Geach'in

72 Bertrand Russell, Human Knowledge: Its Scope and Limits (London: Routledge Classics, 2009), 78. Alıntının sonu bizi başka bir tartışmaya, burada girmediğimiz ama adını andığımız bir tartışmaya götürmektedir. O da özel adların gönderimi -ya da Russell'ın kullandığı şekliyle terimlerin karşılık geldikleri şeyle olan ilişkileri. Russell'ın tümel demeti bağlamında düşündüğü açıklamanın, sonrasında sıkça eleştirildiği açıktır. Örneğin ilk eleştiri Strawson'dan gelmiştir. P. F. Strawson, “On Referring”, Mind, Jul., 1950, Vol. 59, No. 235 (Jul., 1950), 320-344. Sonrasında da özellikle Kripke’nin katı göstericiler kuramı ciddi bir eleştiri olarak görülmektedir. Saul Kripke, Naming and Necessity (Cambridge: Harvard University Press, 1980). Özellikle özel adların doğrudan gönderimi konusu bu bağlamda yeni bir tartışmanın geliştirilmesine olanak sağlamıştır. Ancak şimdilik bu konuya değinmiyoruz. Frege'den başlayarak uzun bir süredir gündemde olan terimlerin gönderimi sorunu hâlâ canlıdır ve tartışılmaktadır. Bkz. Eliot Michaelson ve Marga Reimer, "Reference", The Stanford Encyclopedia of Philosophy, ed. Edward N. Zalta, erişim: 16.11.2020, URL = <https://plato.stanford.edu/archives/spr2019/entries/reference/>. 
ileri sürdüğü üzere varolanın edimsel değişimi üzerinden mi ele almalıyız? Eğer demet kuramları bağlamında bakıyorsak bunun ileri sürülemeyeceği açıktır. Demet kuramlarında bazı özelliklerin daha temel olduğunun savunulması gereklidir. Ancak burada da Geach'in ileri sürdügü türden bir tözün değişimi dolayısıyla değil hangi özelliğin daha temel olduğu üzerinden tartışma yürümektedir. Böylece daha tutarlı bir açıklama sunulmuş olur. Hangi özelliğin içsel ya da dışsal olduğunun belirlenmesi yerine hangisinin ne bakımından daha kökensel olduğunun belirlenmesine uğraşılmalıdır. O zaman özellikler arasındaki farklılıklara kısaca da olsa değinmek bu karanlıktaki yanın ortaya çıkmasına yardımcı olacaktır.

Felsefe tarihinde özsel/ilineksel özellikler ayrımı ya da birincil nitelikler/ikincil nitelikler ayrımları aslında doğrudan doğruya bu konunun felsefe tarihindeki örnekleridir. Çağdaş ontolojik tartışmalarda da özellikler arası hiyerarşi içsel/dışsal özellikler, merkez/çevre özellikler, çekirdek (nuclear)/çevre özellikler ${ }^{73}$, yüklemler/fiziksel özellikler, doğal/az doğal-seyrek/bol ${ }^{74}$ gibi ayrımlar üzerinden sergilenmektedir. ${ }^{75}$ Ancak bu da özelliklerin ne kadar geniş biçimde ele alınması gerekliliğine bağlı görünmektedir. İlk aklımıza gelenler duyulur nitelikler vb. olsa da düşündüğümüzde aslında pek çok şeyin özellik olarak sayılabileceği ortaya çıkmaktadır. Örneğin özellikler Campbell tarafından Black'in makalesinde ya da diğer kuramlarda geçtiğinden daha geniş bir çerçevede ele alınır. Şimdiye kadar genelde örnekler olarak renk, şekil vb. durumları incelemiş olsak da aslında bir nesnenin özelliği dendiğinde pek çok durum düşünülebilir: "katılık, şeffaflık, parlaklık, çok yüzlü olma, karbon yapısında olma, içsel kristal yapı, içsel elektromanyetik ve diğer atom-altı güçler, kütle, hacimlilik, 1 sı vb.”76

Bu türden doğal özelliklerin (ki bunların da bazıları aslında kuram içi özellikler olmaları bakımından zihin bağımlıdırlar) yanı sıra "grue”, "Sokrates tarafından sevilmemek", "yuvarlak kare olmak” gibi dilsel olarak ifade edilebilirlikten hareket eden ancak Geach'in içsel olmayan olarak ifade ettiği türden özellikler de vardır. ${ }^{77}$ Ancak tüm bu özellikler içerisinde nesne bağlamında daha öne çıkan uzam-zamansallık ya da buna ilişkin fiziksel özellikler ve açıklamalar olmaktadır. Bu bağlamda alan-kuramsal bakış açısının da yani doğrudan doğruya fiziğin işaret ettiği özelliklerin devreye girdiği görülmektedir. Elbette tüm bunların içerisinde matematiksel özelliklerin hepsinin de sayılması gerekir.

73 Peter Simons, "Particulars in Particular Clothing: Three Trope Theories of Substance", Philosophy and Phenomenological Research, Vol. 54, No. 3, (Sep. 1994), 553-575.

74 Lewis’e göre özellikler seyrek (doğal özellikleri niteleyenler) (sparse) ve bol (semantik özellikleri yani her türden yüklemi niteleyenler) (abundant) özellikler olarak ayrımlanırsa metafizik açıklamaların gereksindiği açılamalar yapılabilir çünkü seyrek özellikler nesnenin doğasına ilişkindir, içkindir vb. Ancak diğer yanda dilsel yaklaşımlardan kaynaklanan sorunlara da çözüm getirilebilir çünkü bol özellikler yüklemlere karşılık gelen özellikler olarak düşünülür. Bu ayrım aynı zamanda bazılarının doğal bazılarınınsa az doğal olmalarıyla da ilgilidir. David Lewis, On The Plurality of Worlds (Oxford: Blackwell, 1986), 59-60.

75 Farklı bakış açıları için Bkz. Francesco Orilia ve Michele Paolini Paoletti, "Properties", The Stanford Encyclopedia of Philosophy, ed. Edward N. Zalta, erişim: 16.11.2020, URL = <https://plato.stanford.edu/archives/win2020/entries/ properties/>.

76 Campbell, Abstract Particulars, 20.

77 Cian Dorr, "Natural Properties", The Stanford Encyclopedia of Philosophy, ed. Edward N. Zalta, erişim: 16.11.2020, $\mathrm{URL}=<$ https://plato.stanford.edu/archives/fall2019/entries/natural-properties/>. 
Trop demetleri, özelliklerin tikeller olmasıyla doğallığında belli bir uzam-zamansal bulunuşu taşırlar. Bir başka anlamda, troplar tümellerden farklı olarak zaten bu dünyalıdırlar ve kendi konumlarını bir konumluluk ile işaret ederler. Dolayısıyla trop demeti kuramlarının uzamzaman ilişkilerine gereksinimi ile tümel demeti kuramlarının bu ilişkilere gereksinimi farklıdır. Trop demeti kuramlarının farklı uzam-zamansal kuramlarla birlikte yeniden üretilebileceği ortaya çıkmaktadır. Bir anlamda bu ve şu tekil kırmızılık yerine burada ve şurada tekil kırmızılıklar olarak nitelenebilmeleri olanağı bulunmaktadır.

Burada önemli olan ne türden bir uzam-zaman anlayışına sahip olduğunuz değildir. Her türden uzam-zaman anlayışı tropların eşbulunuşluluğunu destekleyebilmek adına kullanılabilir görünmektedir. Uzam-zaman noktaları büyük oranda alan-kuramsal bir anlayışla kendi kimi özeliklerine sahip olarak anlaşılmaktadır. Bunu sanki özellikler uzam-zaman noktalarının bizzat kendilerine iğnelenmişler ve bu sayede de bulundukları konumu var kılıyorlar olarak niteleyebiliriz. Elbette bu görüşler güncel fiziğin verileri ile desteklenmeli ya da geliştirilmelidir.

\section{Sonuç}

Geach'in Cambridge Değişimi olarak ifade ettiği değişim tanımı, arkasındaki metafizik yaklaşım devre dışı bırakıldığında elbette çok geniş bir değişim tanımı olmakla eleştirilebilir. Aslında her değişim bir Cambridge Değişimidir ancak bunlardan bazıları daha başka türden değişim olabilirler. Geach bu konuda haklı olsa da değişimde değişen şeyin nasıl belirleneceği sorgu konusu edildiğinde (çünkü Geach'e göre bir şeyin gerçek değişim olduğunun anlaşılabilmesi için nesnesine bakılması gerekir), nesne kuramlarının tartışılması bir zorunluluktur. Bu da Cambridge Değişimi konusunda eleştirel tavır takınan bakış açısını yanlışlamamızın olanağını yaratır. Her ne kadar ilgili tartışmalar sonucunda Geach'in de ifade ettiği üzere özellikler arasında farklılık çizme zorunluluğu ortaya çıkmış olsa da aslında bu zorunluluğa ancak nesne bağlamındaki tartışmanın yürütülmesiyle varılabilir. Bu da genel olarak özne-yüklem ifadeleri ve bunların karşılık geldiği (iddia edilen) varolanların ontolojik durumunun tartışılmasını gerektirir. Böylece başa dönmek gerekir: Cambridge Değişimi merkeze konmadan ve ilgili değişim ifadeleri incelenmeden, bunların işaret ettikleri varsayılan varolanlar hakkında bir kuram geliştirmeden Geach'in eleştirisinin haklılığından söz edilemez.

Hakem Değerlendirmesi: Dış bağımsız.

Çıkar Çatışması: Yazar çkar çatış̧ması bildirmemiștir.

Finansal Destek: Yazar bu çalışma için finansal destek almadığını beyan etmiştir.

Peer-review: Externally peer-reviewed.

Conflict of Interest: The author has no conflict of interest to declare.

Grant Support: The author declared that this study has received no financial support. 


\section{Kaynaklar / References}

Allaire, Edwin B. "Bare Particulars." Philosophical Studies: An International Journal for Philosophy in the Analytic Tradition, Vol. 14, No. 1/2 (Jan. - Feb., 1963): 1-8.

Armstrong, D. M. Universals: an opinionated introduction. London: Westview Press, 1989.

Bergmann, Gustav. Realism: a critique of Brentano and Meinong. Madison: University of Wisconsin Press, 1967.

Berto, Franceso ve Matteo Plebani. Ontology and Metaontology: A Contemporary Guide. Bloomsbury Academic, 2015.

Black, Max. "The Identity of Indiscernibles." Metaphysics: contemporary readings. ed. M. J. Loux, 104-114. NY: Routledge, 2005.

Bradley, H. F. Appearance and Reality: a metaphysical essay. 6th Imp. London: George Allen \& Unwin LTD, 1916.

Butchvarov, Panayot. "The Ontology of Philosophical Analysis." Noûs, Mar., 1981, Vol. 15, No. 1, (1981): 3-14.

Campbell, Keith. Abstract Particulars. Oxford: Basil Blackwell Ltd., 1990.

Denkel, Arda. "Substance Without Substratum." Philosophy and Phenomenological Research Vol. 52, No. 3, (Sep., 1992), 705-711.

Dorr, Cian. "Natural Properties". The Stanford Encyclopedia of Philosophy, Ed. Edward N. Zalta, URL = $<$ https://plato.stanford.edu/archives/fall2019/entries/natural-properties/>. Erişim: 16.11.2020.

Geach, Peter, God and the Soul. London: Routledge and Kegan Paul. 1969.

Geach, Peter. Logic Matters. Oxford: Blackwell Pub, 1973.

Geach, P. ve Robert H. Stoothoff, "What Actually Exists." Proceedings of the Aristotelian Society, Supplementary Volumes. Vol. 42 (1968): 7-30.

Gözcü, A. Suat. “ZAMAN SORUNU: ŞİMDİCİ VE EBEDIYYTÇİ ZAMAN ANLAYIŞLARI”, Kutadgubilig Felsefe-Bilim Araştırmaları, Eylül 2018, Sayı 38, 41-65.

Kripke, Saul. Naming and Necessity. Cambridge: Harvard University Press, 1980.

Lewis, David. On The Plurality of Worlds. Oxford: Blackwell, 1986.

Locke, J. Essay Concerning Human Understanding. ed. J. Yolton. London: Dent, 1961.

Lombard, Lawrence Brian. "Relational Change and Relational Changes." Philosophical Studies: An International Journal for Philosophy in the Analytic Tradition. Jul., 1978, Vol. 34, No. 1 (Jul., 1978): 63-79.

Loux, Michael J. Metaphysics: a contemporary introduction. London: Routledge Taylor\&Francis Group, 2006.

Loux, Michael J. Substance and Attribute: a study in ontology. Holland: D. Reidel Pub. Com., 1978.

Lowe, E. J. "Individuation." The Oxford Handbook of Metaphysics, 75-95. Ed. Loux\&Zimmerman. Oxford: Oxford University Press, 2003.

Martin, C. B. "Substance substantiated." Australasian Journal of Philosophy, 58:1, (1980): 3-10.

McTaggart, J.M.E. “The Unreality of Time”, Mind, 17(68) (1908): 457-474.

McTaggart, J.M.E. Studies in the Hegelian Dialectic. Cambridge: Cambridge University Press, 1922.

Michaelson, Eliot ve Marga Reimer, "Reference", The Stanford Encyclopedia of Philosophy, ed. Edward N. Zalta, URL $=<$ https://plato.stanford.edu/archives/spr2019/entries/reference/ $>$. Erişim: 16. 11. 2020.

Mortensen, Chris, "Change and Inconsistency." The Stanford Encyclopedia of Philosophy, ed. Edward N. Zalta, $\mathrm{URL}=<$ https://plato.stanford.edu/archives/spr2020/entries/change/>. Erişim: 16. 11. 2020.

Orilia, Francesco ve Michele Paolini Paoletti, "Properties." The Stanford Encyclopedia of Philosophy, ed. Edward N. Zalta, URL = <https://plato.stanford.edu/archives/win2020/entries/properties/>. Erişim: 16. 11. 2020. 
Quine, W.V.O. From a Logical Point of View. Cambridge: Harvard University Press, 1980.

Robinson, Howard. "Substance", The Stanford Encyclopedia of Philosophy, ed. Edward N. Zalta, URL = <http://plato.stanford.edu/archives/spr2014/entries/substance/> Erişim: 26 Ağustos 2020.

Russell, Bertrand. “On Denoting.” Mind 114, no. 456 (2005): 873-87.

Russell, Bertrand. "The Problem of Universals." Russell on Metaphysics: selections from the writings of Bertrand Russell. ed. S. Mumford, 143-161. London: Routledge, 2003.

Russell, Bertrand. An Inquiry Into Meaning and Truth. London: George Allen\&Unwin Ltd, 1956.

Russell, Bertrand. Felsefe Sorunları. çev. Vehbi Hacıkadiroğlu. İstanbul: Kabalcı Yayınevi, 2000.

Russell, Bertrand. Human Knowledge: Its Scope and Limits. London: Routledge Classics, 2009.

Russell, Bertrand. Principles of Mathematics, London: Routledge, 1937.

Simons, Peter. "Particulars in Particular Clothing: Three Trope Theories of Substance." Philosophy and Phenomenological Research, Vol. 54, No. 3, (Sep. 1994): 553-575.

Strawson, P. F. “On Referring.” Mind, Jul., 1950, Vol. 59, No. 235 (Jul., 1950): 320-344.

Van Cleve, James. "Three Versions of Bundle Theory”, Metaphysics: contemporary readings. Ed. M. J. Loux, 121-134. NY: Routledge, 2005. 